\title{
Zinc/Aluminium-Quinclorac Layered Nanocomposite Modified Multi-Walled Carbon Nanotube Paste Electrode for Electrochemical Determination of Bisphenol A
}

\author{
Rahadian Zainul 1,*, Nurashikin Abd Azis ${ }^{2}$, Illyas Md Isa 2,3,*, Norhayati Hashim 2,3, \\ Mohamad Syahrizal Ahmad ${ }^{2,3}$, Mohamad Idris Saidin ${ }^{2}$ and Siriboon Mukdasai ${ }^{4}$ \\ 1 Department of Chemistry, Faculty of Mathematics and Natural Science, Universitas Negeri Padang, \\ West Sumatera 25171, Indonesia \\ 2 Department of Chemistry, Faculty of Science and Mathemathics, Universiti Pendidikan Sultan Idris, \\ Tanjong Malim 35900, Perak, Malaysia; nurashikinazis91@gmail.com (N.A.A.); \\ norhayati.hashim@fsmt.upsi.edu.my (N.H.); syahrizal@fsmt.upsi.edu.my (M.S.A.); \\ idris.saidin@fsmt.upsi.edu.my (M.I.S.) \\ 3 Nanotechnology Research Centre, Faculty of Science and Mathemathics, Universiti Pendidikan Sultan Idris, \\ Tanjong Malim 35900, Perak, Malaysia \\ 4 Department of Chemistry, Faculty of Science, Khon Kaen University, Khon Kaen 40002, Thailand; \\ sirimuk@kku.ac.th \\ * Correspondence: rahadianzmsiphd@fmipa.unp.ac.id (R.Z.); illyas@fsmt.upsi.edu.my (I.M.I.); \\ Tel.: +62-812-6138-53 (R.Z.); +60-154-879-7714 (I.M.I.)
}

Received: 7 January 2019; Accepted: 15 February 2019; Published: 22 February 2019

\begin{abstract}
This paper presents the application of zinc/aluminium-layered double hydroxide-quinclorac (Zn/Al-LDH-QC) as a modifier of multiwalled carbon nanotubes (MWCNT) paste electrode for the determination of bisphenol A (BPA). The Zn/Al-LDH-QC/MWCNT morphology was examined by a transmission electron microscope and a scanning electron microscope. Electrochemical impedance spectroscopy was utilized to investigate the electrode interfacial properties. The electrochemical responses of the modified electrode towards BPA were thoroughly evaluated by using square-wave voltammetry technique. The electrode demonstrated three linear plots of BPA concentrations from $3.0 \times 10^{-8}-7.0 \times 10^{-7} \mathrm{M}\left(R^{2}=0.9876\right), 1.0 \times 10^{-6}-1.0 \times 10^{-5} \mathrm{M}\left(R^{2}=0.9836\right)$ and $3.0 \times 10^{-5}-3.0 \times$ $10^{-4} \mathrm{M}\left(R^{2}=0.9827\right)$ with a limit of detection of $4.4 \times 10^{-9} \mathrm{M}$. The electrode also demonstrated good reproducibility and stability up to one month. The presence of several metal ions and organic did not affect the electrochemical response of BPA. The electrode is also applicable for BPA determination in baby bottle and mineral water samples with a range of recovery between $98.22 \%$ and $101.02 \%$.
\end{abstract}

Keywords: bisphenol A; square-wave voltammetry; layered double hydroxide nanocomposite

\section{Introduction}

Bisphenol A (BPA), is an organic compound consist of two phenol functional groups. It is extensively used as a monomer to manufacture epoxy resins and polycarbonates (PC) plastic [1,2]. There are various ways BPA can be spread into the environment such as via wastewater during the production or via leaching process of epoxy resin and PC plastic products, including food package, water bottles and baby bottles [3]. Further, BPA has been proven by many studies as an endocrine-disrupting chemical $[4,5]$. By mimicking the role of endogenous hormones, BPA can give an adverse effect on the human central nervous system and reproductive system $[6,7]$. Besides that, newborns and infants are potentially exposed to BPA because it can also be found 
in breast milk [8], powdered milk and infant formulas [9]. Until now, the determination of BPA has been carried out by many analytical techniques such as gas chromatography-mass spectrometry [10], spectrophotometric [11], capillary electrophoresis [12], immunoassay detection [13], chemiluminescence detection [14], as well as enzyme-linked immunosorbent assay (ELISA) [15].

Despite the fact that all the analytical techniques named above have high sensitivity with low detection limit, they are relatively expensive instruments and required time-consuming sample pretreatment, making them unsuitable for on-site analysis. Some of them are not user-friendly and need to be by handled by skillful technicians. Since BPA is high electrochemically active, electrochemical sensor acts as an attractive alternative for their determination, possess the merit of simple operating, fast response, economical, and suitable for on-site analysis. However, the electron transfer of BPA at bare electrodes is slow, which further can affect their sensitivity. For that reason, some functional materials have been introduced to develop BPA sensor with high sensitivity of detection such as Au nanoparticles [16-18], $\mathrm{NiO}$ nanocomposite [19,20], ferroferric oxide nanoparticles [21,22] and $\mathrm{Bi}_{2} \mathrm{WO}_{6}$ nanoplate [23] but the sensor still provided a narrow working range. The layered material nanocomposites with the magnetic properties of the metal are remarkably sensitive to the intercalation of molecular anions. For example, the presence of zinc in nanocomposite aided in the intercalation of hydroxide-2(3-chlorophenoxy) propionate and 2(3-chlorophenoxy) propionate resulting in the material which feasible for sensor applications [24-26]. Recently, the intercalation of quinclorac (QC) with host material layered double hydroxide (LDH) has potential to be used as a modifier for electrode [27]. QC, which is known as 3,7-dichloro-8-quinolinecarboxylic acid is a type of herbicide that was broadly used in paddy cultivation. Besides that, it is beneficial in controlling of some broad leaf weeds and grass in crops [28]. The chemical structure of QC is shown in Figure 1.

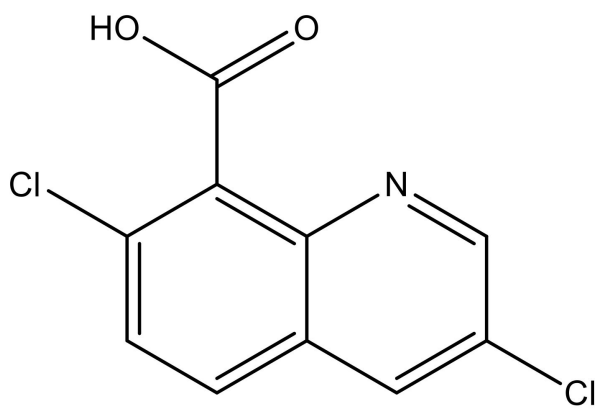

Figure 1. The chemical structure of quinclorac (QC).

A number of carbon-based materials such as graphite, glassy carbon (GC), carbon fibers and carbon nanotubes (CNTs) are commonly used in electrochemical analysis as conductive materials. These materials are extensively employed in sensor fabrication because they have a wide potential window, rich surface chemistry, chemical inertness, and also economical [29]. Among them, carbon nanotubes (CNTs) have gained much attention in the preparation of a mixture of carbon paste electrode (CPE). One of the CNTs types which are multiwalled carbon nanotubes (MWCNTs), has many advantages such as small in size, high specific surface area, high chemical stability, high electrical and thermal conductivity and high mechanical strength, making them superiority over other types of carbon-based materials [30]. High surface area to volume ratio materials are more exposed for reaction and they will react at a much faster rate, the further effect on improved mass transport characteristics. This will promote the electron transfer between the electroactive species and the electrode surface [31]. Compared to other small metallic structures, the MWCNTs are higher in term of stability against electromigration [32].

There is a need for developing an economical and simple yet high-sensitivity method for determination of BPA. For that purpose, this paper presents the modification of MWCNT with layered material nanocomposite of zinc/aluminium-quinclorac for determination of BPA by using square-wave voltammetry technique. 


\section{Materials and Methods}

\subsection{Chemicals and Reagents}

BPA used was from Sigma-Aldrich Co. (St. Louis, MO, USA). A stock solution of $0.01 \mathrm{M}$ BPA was prepared with ethanol $(95 \% \mathrm{v} / \mathrm{v})$ and kept in a refrigerator at $4{ }^{\circ} \mathrm{C}$. Working solutions were freshly prepared before use by diluting the stock solution in supporting electrolyte. Potassium phosphate buffer solution (PBS) was prepared by $0.1 \mathrm{M} \mathrm{KH}_{2} \mathrm{PO}_{4}$ and $0.1 \mathrm{M} \mathrm{K}_{2} \mathrm{HPO}_{4}$. MWCNT (Timesnano, Chengdu, China) and all analytical grade reagents were used as received without further purification. All the solutions were prepared with deionized water (EASY pure LF, Barnstead, Essex, UK).

\subsection{Apparatus}

Square-wave voltammetry (SWV) and electrochemical impedance spectroscopy (EIS) studies were conducted using a potentiostat, model Series-G750 and model Ref 3000, respectively. $\mathrm{Zn} / \mathrm{Al}-\mathrm{LDH}-\mathrm{QC} / \mathrm{MWCNT}$ paste electrode acted as a working electrode, while both reference and counter electrodes were represented by platinum wire and $\mathrm{Ag} / \mathrm{AgCl}$, respectively. The morphological studies of the Zn/Al-LDH-QC/MWCNT were examined by scanning electron microscope (SEM) and transmission electron microscope (TEM), model SU8020 UHR (Hitachi, Japan). The pH measurements were carried out using Thermo Scientific Orion 2-Star Benchtop pH Meter (Thermo Fisher Scientific, Chelmford, MA, USA), which was calibrated with standard $\mathrm{pH}$ buffer solutions.

\subsection{Synthesis of Zn/Al-LDH-QC Nanocomposite}

By using $\mathrm{Zn}\left(\mathrm{NO}_{3}\right)_{2}$ and $\mathrm{Al}\left(\mathrm{NO}_{3}\right)_{3}$ as precursors, the $\mathrm{Zn} / \mathrm{Al}-\mathrm{LDH}$ were synthesized by a conventional co-precipitation method as previously reported [27]. Both precursors were dissolved in $250 \mathrm{~mL}$ of deionized water. $50 \mathrm{~mL}(0.05 \mathrm{M}, 0.1 \mathrm{M}$ and $0.2 \mathrm{M})$ of QC solution was then added and the mixture was stirred. The $\mathrm{pH}$ of the solution was adjusted to 7.5 with sodium hydroxide. The slurry was aged for $24 \mathrm{~h}$ in oil bath shaker at $70^{\circ} \mathrm{C}$. The resulting precipitate was then centrifuged, washed by deionized water and dried in an oven at $60^{\circ} \mathrm{C}$. Finally, the dried precipitate of $\mathrm{Zn} / \mathrm{Al}-\mathrm{LDH}-\mathrm{QC}$ was finely ground and kept in a glass bottle at room temperature until the subsequent experiment.

\subsection{Preparation of Electrodes}

A paste of the proposed electrodes was prepared by mixing Zn/ Al-LDH-QC ( $0 \%, 5 \%, 10 \%, 15 \%)$ and MWCNT $(100 \%, 95 \%, 90 \%, 85 \%)$ via hand mixing in a mortar and pestle (Figure 2$)$. The mixture was then added with two drops of liquid binder (paraffin oil). Next, the homogenized paste obtained was firmly packed into a Teflon tube (i.d. $2.0 \mathrm{~mm}$ ). One end of the tube was connected to copper wire in order to produce an electrical contact between paste and wire. Prior to each measurement, the electrode surface was smoothened with soft paper.

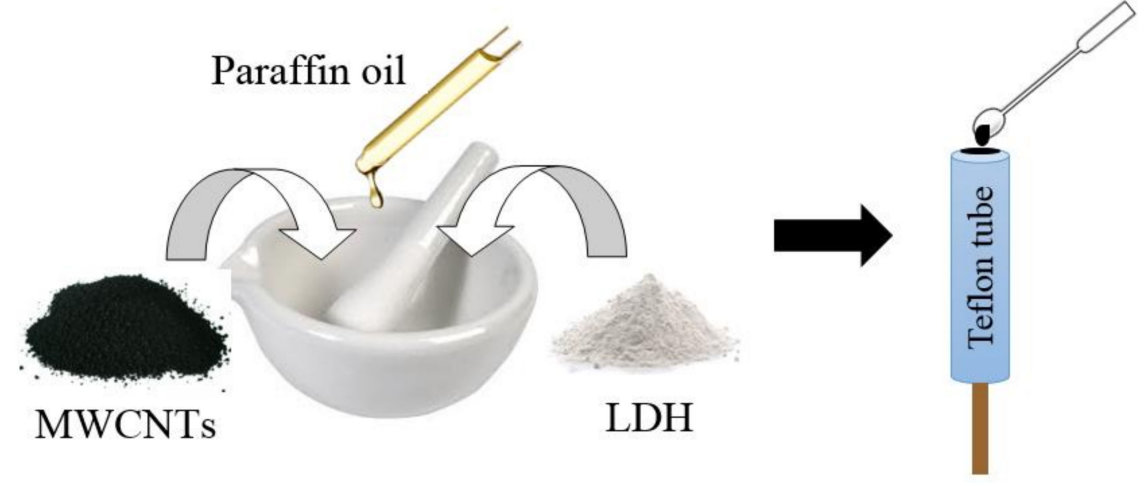

Figure 2. Preparation of the modified electrode (MWCNTs: multiwalled carbon nanotubes, LDH: layered double hydroxide). 


\subsection{Measurement Procedure}

Voltammetric measurements were performed in the desired concentration of BPA solution containing 0.1 M PBS, at pH 7.0. Before each measurement, the solutions were deoxygenated by nitrogen gas purge for 15 minutes. The voltammetric measurement was recorded using SWV in the potential range from $-0.2 \mathrm{~V}$ to $+1.0 \mathrm{~V}$ at $150 \mathrm{~Hz}$ frequency, $6 \mathrm{mV}$ step increment, and $60 \mathrm{mV}$ pulse height. All the experiments were carried out at room temperature of $25 \pm 2{ }^{\circ} \mathrm{C}$.

\subsection{Real Samples}

A baby bottle was thoroughly washed prior the analysis. The bottle was filled with deionized water and heated for $1 \mathrm{~h}$ at $70{ }^{\circ} \mathrm{C}$ and 4 hours at $30^{\circ} \mathrm{C}$. Then, the baby bottle was left for a week at room temperature. The solution was then added with $1.0 \mathrm{~mL}$ of ethanol. Finally, the solution was filtrated and diluted with PBS. Two mineral water samples were purchased. The first mineral water sample was left for two weeks in a car exposed to sunlight, while the other mineral water sample was filled with deionized water and heated for $5 \mathrm{~h}$ at $60^{\circ} \mathrm{C}$. Then both samples were directly tested without any pretreatments.

\section{Results}

\subsection{Surface Morphology Studies of Zn/Al-LDH-QC-MWCNT}

SEM and TEM were used to examine the morphology of Zn/Al-LDH-QC and Zn/Al-LDH-QC/ MWCNT. From the previous report on characterization of Zn/Al-LDH and Zn/Al-LDH-QC, Figure 3A indicates a smaller and irregular particle size of Zn/Al-LDH-QC with a fine plate-like characteristics [27]. The transparent delicate tube in Figure 3B representing MWCNT and they were covered by opaque features of $\mathrm{Zn} / \mathrm{Al}-\mathrm{LDH}-\mathrm{QC}$.

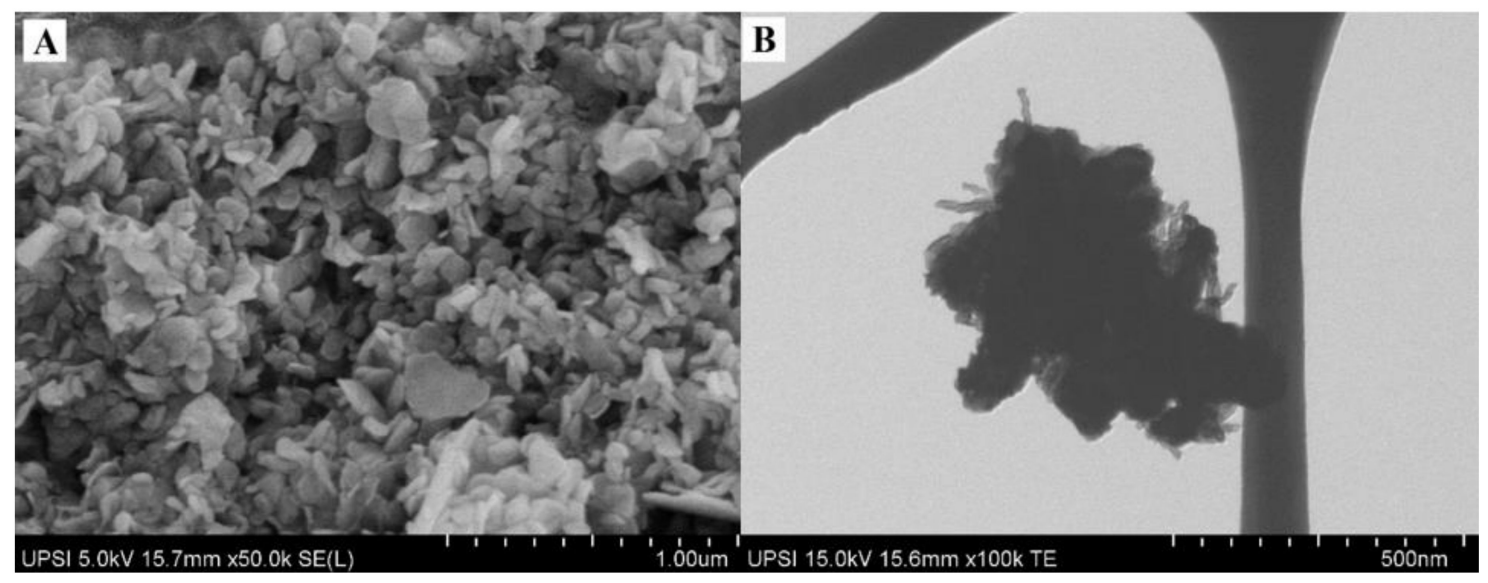

Figure 3. (A) SEM image of Zn/Al-LDH-QC and (B) TEM image of Zn/Al-LDH-QC/MWCNT.

\subsection{Electrode Characterization}

Figure 4 shows a well-defined cyclic voltammogram $(\mathrm{CV})$ in $4.0 \mathrm{mM} \mathrm{K} \mathrm{K}_{3}\left[\mathrm{Fe}(\mathrm{CN})_{6}\right]$. Compared to the MWCNT paste electrode (curve a), the Zn/Al-LDH-QC/MWCNT paste electrode (curve b) showed increasing in redox currents. Both anodic peak current $\left(\mathrm{I}_{\mathrm{pa}}\right)$ and cathodic peak current $\left(\mathrm{I}_{\mathrm{pc}}\right)$ calculated from MWCNT paste electrode were $5.064 \mu \mathrm{A}$ and $2.873 \mu \mathrm{A}$, respectively. Meanwhile, the redox peak current of Zn/Al-LDH-QC/MWCNT paste electrode was enhanced to $\mathrm{I}_{\mathrm{pa}}=7.962 \mu \mathrm{A}$ and $\mathrm{I}_{\mathrm{pc}}=4.040 \mu \mathrm{A}$. Additionally, peak-to-peak separation $\left(\Delta \mathrm{E}_{\mathrm{p}}\right)$ of $\mathrm{Zn} / \mathrm{Al}-\mathrm{LDH}-\mathrm{QC} / \mathrm{MWCNT}$ paste electrode also decreased from $0.366 \mathrm{~V}$ to $0.333 \mathrm{~V}$. These results suggested that the implementation of modifier Zn/ Al-LDH-QC in the MWCNT paste electrode contributed to improving the electrochemical response of the electrode in terms of electron-transfer rate and conductivity. 


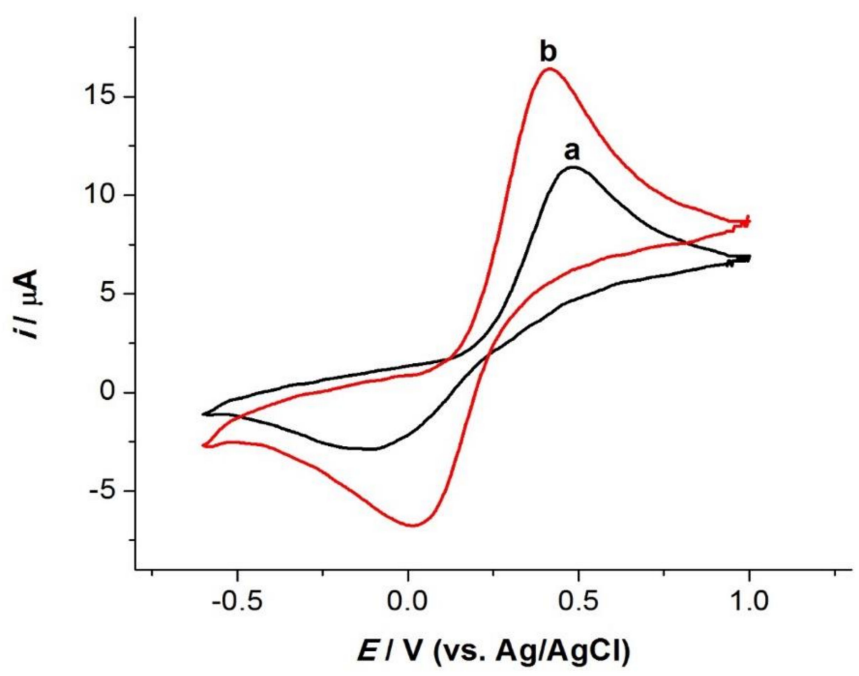

Figure 4. Cyclic voltammogram of (a) MWCNT paste electrode and (b) Zn/Al-LDH-QC/MWCNT paste electrode at $100 \mathrm{mVs}^{-1}$. Solution: $4.0 \mathrm{mM} \mathrm{K}_{3}\left[\mathrm{Fe}(\mathrm{CN})_{6}\right]$.

Electrochemical impedance spectroscopy (EIS) was performed to evaluate the capability of electron transfer of the electrode. Generally, Nyquist plot of the EIS consists of two portions which are a semicircle portion and a linear portion. The linear portion corresponds to the diffusion process. The semicircle diameter represents the electron-transfer resistance $\left(R_{\mathrm{ct}}\right)$ at the surface of electrode [33]. Figure 5 illustrated the Nyquist plot of MWCNT paste electrode (curve a) and $\mathrm{Zn} / \mathrm{Al}-\mathrm{LDH}-\mathrm{QC} / \mathrm{MWCNT}$ (curve b) paste electrode. Both electrodes showed almost straight lines, revealing that $\mathrm{Zn} / \mathrm{Al}-\mathrm{LDH}-\mathrm{QC}$ attributed the ability good electron transfer. By fitting the Randles equivalent electrical circuits (Figure 5 inset), the $R_{\text {ct }}$ values for the unmodified MWCNT paste electrode was 34.03 ohms. After the modification of the electrode using Zn/Al-LDH-QC, the value of $R_{\mathrm{ct}}$ decreased to $0.101 \mathrm{ohms}$, which was smaller than the unmodified MWCNT paste electrode. It was contributed by the presence of high conductive modifier in the MWCNT paste electrode.

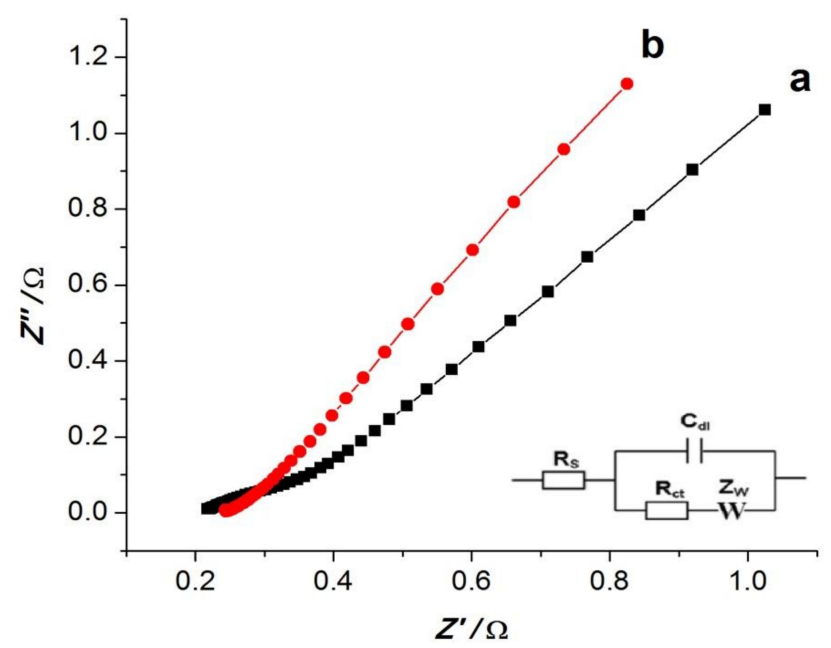

Figure 5. Nyquist plot of the (a) MWCNT paste electrode, and (b) Zn/Al-LDH-QC/MWCNT paste electrode. Solution: $4.0 \mathrm{mM} \mathrm{K}_{3}\left[\mathrm{Fe}(\mathrm{CN})_{6}\right]$.

In addition, the electron transfers apparent rate constant $\left(k_{\text {apps }}\right)$ value was calculated from Equation (1);

$$
k_{\text {apps }}=\frac{R T}{F^{2} R_{\mathrm{ct}} C}
$$


where, $R=$ Gas constant $\left(8.314 \mathrm{~J} \mathrm{~mol}^{-1} \mathrm{~K}^{-1}\right) ; T=$ Absolute temperature $(298 \mathrm{~K}) ; \mathrm{F}=$ Faraday constant $\left(96485 \mathrm{C} \mathrm{mol}^{-1}\right) ; C=\mathrm{K}_{3}[\mathrm{Fe}(\mathrm{CN})]_{6}$ solution concentration.

The $k_{\text {apps }}$ values calculated for MWCNT paste electrode and Zn/Al-LDH-QC/MWCNT paste electrode were $1.96 \times 10^{-6} \mathrm{~cm} \mathrm{~s}^{-1}$ and $6.65 \times 10^{-4} \mathrm{~cm} \mathrm{~s}^{-1}$, respectively. The Zn/Al-LDH-QC/MWCNT paste electrode showed high $k_{\text {apps }}$ and low $R_{\mathrm{ct}}$ values which indicates a faster electron-transfer process. This process has been speeding up by the Zn/Al-LDH-QC. The EIS result consents very well with the CV findings. Scheme 1 illustrates the electro-oxidation process of BPA which involved two electrons and two protons, and the oxidation reaction of BPA on the electrode surface during electrochemical sensing.

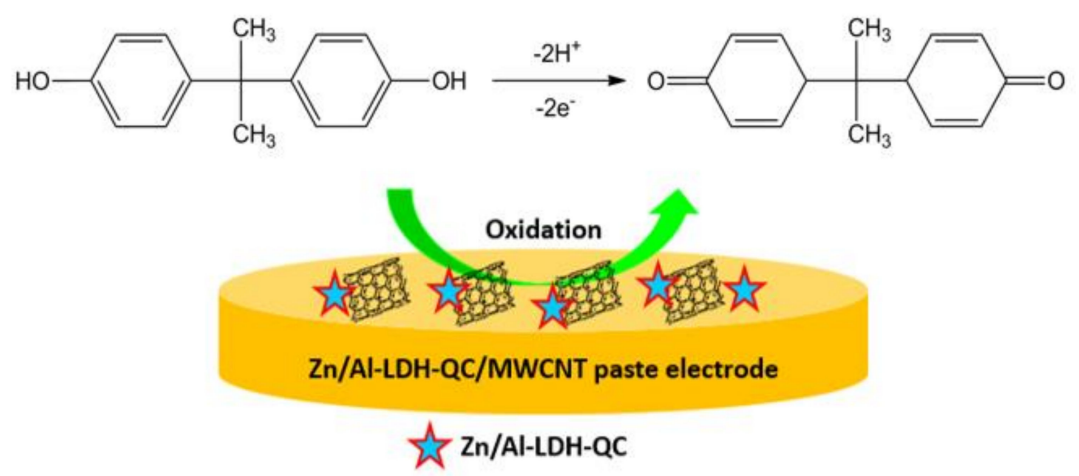

Scheme 1. The elector-oxidation reaction of bisphenol A on electrode surface during electrochemical sensing.

\subsection{Optimization of the Experimental Conditions}

\subsubsection{Effect of Modifier Content}

In this experiment, the SWV was employed to study the electrochemical performance of different composition ratios (\% w/w) between Zn/Al-LDH-QC and MWCNT in $0.1 \mathrm{mM}$ BPA. As illustrated in Figure 6, the current response increased with composition ratios of Zn/Al-LDH-QC in MWCNT paste electrode and achieved the maximum at $10 \%$, further increase the percent of modifier caused a current response to decrease. This phenomenon corresponds to an excessive amount of $\mathrm{Zn} / \mathrm{Al}-\mathrm{LDH}-\mathrm{QC}$ in MWCNT paste electrode would reduce the conductivity of the surface of the electrode and their charge transfer kinetics. Besides that, the excessive amount of modifier will form a thick film and further limited the mass transport of BPA at electrode surface [34]. Therefore, the modified MWCNT paste electrode with $10 \%$ of $\mathrm{Zn} / \mathrm{Al}-\mathrm{LDH}-\mathrm{QC}$ was implemented for subsequent experiments.

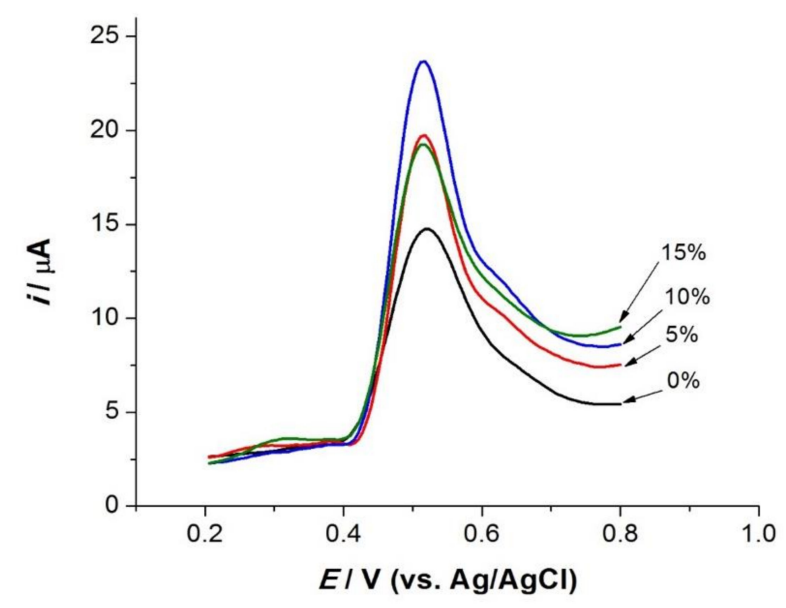

Figure 6. Square wave voltammetry of $0.1 \mathrm{mM}$ BPA at Zn/Al-LDH-QC/MWCNT paste electrode with different percent of Zn/Al-LDH-QC. 


\subsubsection{Effect of $\mathrm{pH}$}

The electrochemical response may be affected by $\mathrm{pH}$ of the analyte solution. In this study, the current peak of BPA increased from pH 6.0 to 7.4 (Figure 7). Meanwhile, at pH exceed 7.4, the current peak started to decline. This could be ascribed to the competition that occurred between hydroxyl anion and BPA molecule on the surface of the electrode. Therefore, $\mathrm{pH} 7.4$ was used in all the following experiments. Besides that, increasing of $\mathrm{pH}$ also caused negatively shifting of the peak potential. The equation of this relationship can be derived as of $E_{\mathrm{pa}}(\mathrm{V})=-0.0541 \mathrm{pH}+0.9139\left(R^{2}=0.9942\right)$. The $0.0541 \mathrm{~V} / \mathrm{pH}$ shift obtained was approximately near to the Nernst value $(0.0576 \mathrm{~V} / \mathrm{pH})$ indicating a balanced number of protons and electrons transfer in the electrode reaction.

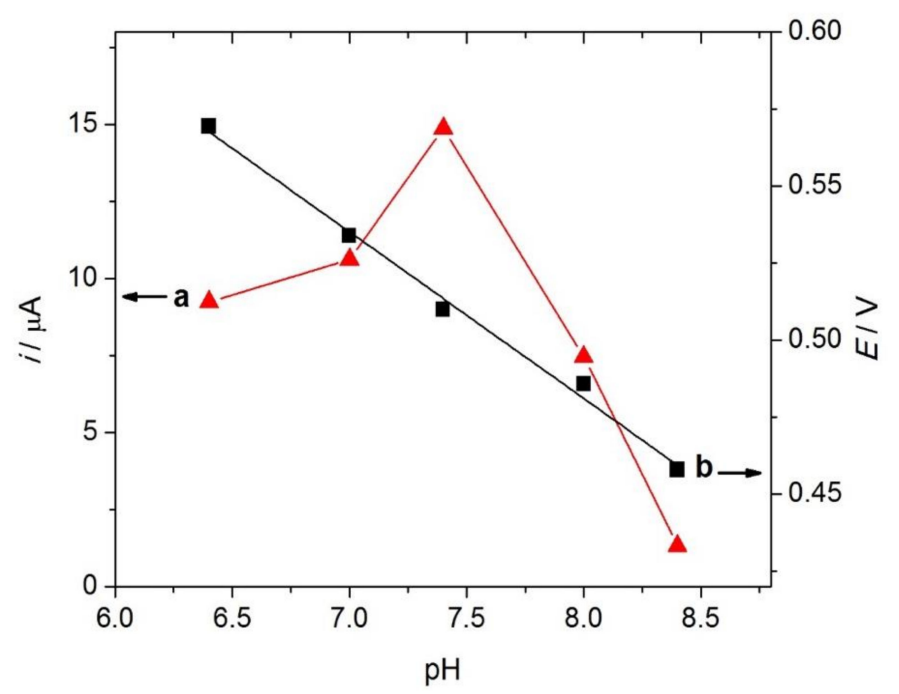

Figure 7. Graph of (a) current response on varying $\mathrm{pH}$ value and (b) influence of $\mathrm{pH}$ changes on peak potential.

\subsubsection{Effect of Electrolytes}

The effect of several types of supporting electrolytes such as $\mathrm{NaCl}, \mathrm{KCl}, \mathrm{KNO}_{3}, \mathrm{Na}_{2} \mathrm{SO}_{4}$, $\mathrm{CH}_{3} \mathrm{COONa}$, and PBS towards BPA response was studied. As shown in Figure 8, the SWV voltammogram displays a higher $I_{\mathrm{pa}}$ and better peak shape in PBS compared to the other supporting electrolytes, thus PBS was chosen as suitable supporting electrolyte for further studies.

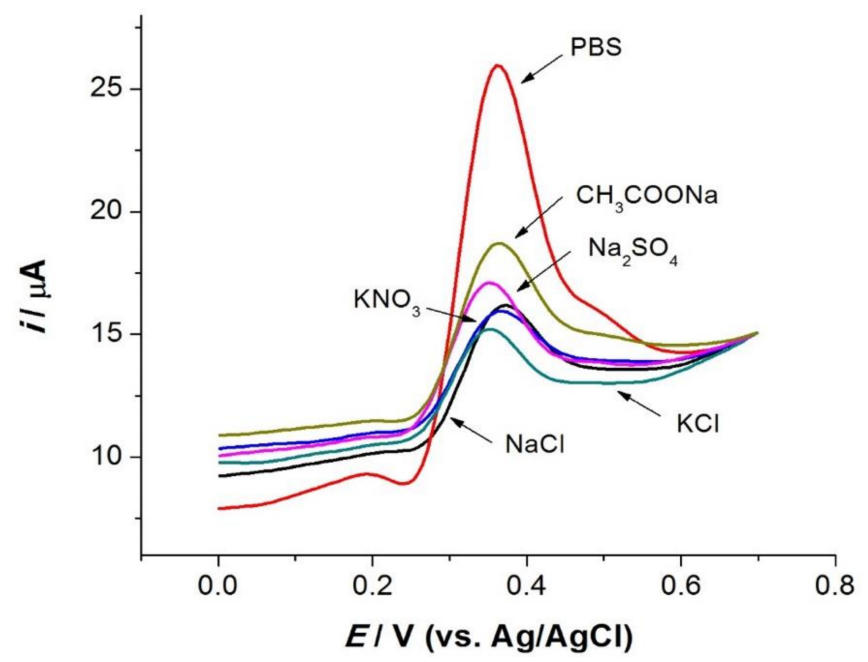

Figure 8. Effect of electrolytes on the response of $0.1 \mathrm{mM}$ BPA. 


\subsubsection{Effect of SWV Parameters}

Based on the calculations performed by Osteryoung, SWV characteristics are influenced by some parameters that applied in the experiments [35]. Therefore, SWV parameters such as frequency, pulse size, and step size were further investigated in detail. The influence of frequency (30 to $160 \mathrm{~Hz}$ ) towards current response was investigated (Figure 9A), and the peak current was found to be linearly to frequency. Therefore, $160 \mathrm{~Hz}$ was chosen as an optimum frequency as it generated a very good resolution. As shown in Figure 9B, the range of pulse size between $20 \mathrm{mV}$ and $70 \mathrm{mV}$ was evaluated, and the highest current peak exhibited by pulse size $60 \mathrm{mV}$. The increasing of step size from $1 \mathrm{mV}$ to $6 \mathrm{mV}$ caused the current peak to increase (Figure 9C), hence, $6 \mathrm{mV}$ was chosen as the optimum step size with a sharper peak. Therefore, the optimum SWV conditions (frequency: $160 \mathrm{~Hz}$, pulse size: $60 \mathrm{mV}$, step size: $6 \mathrm{mV}$ ) were applied for better sensitivity and resolution.
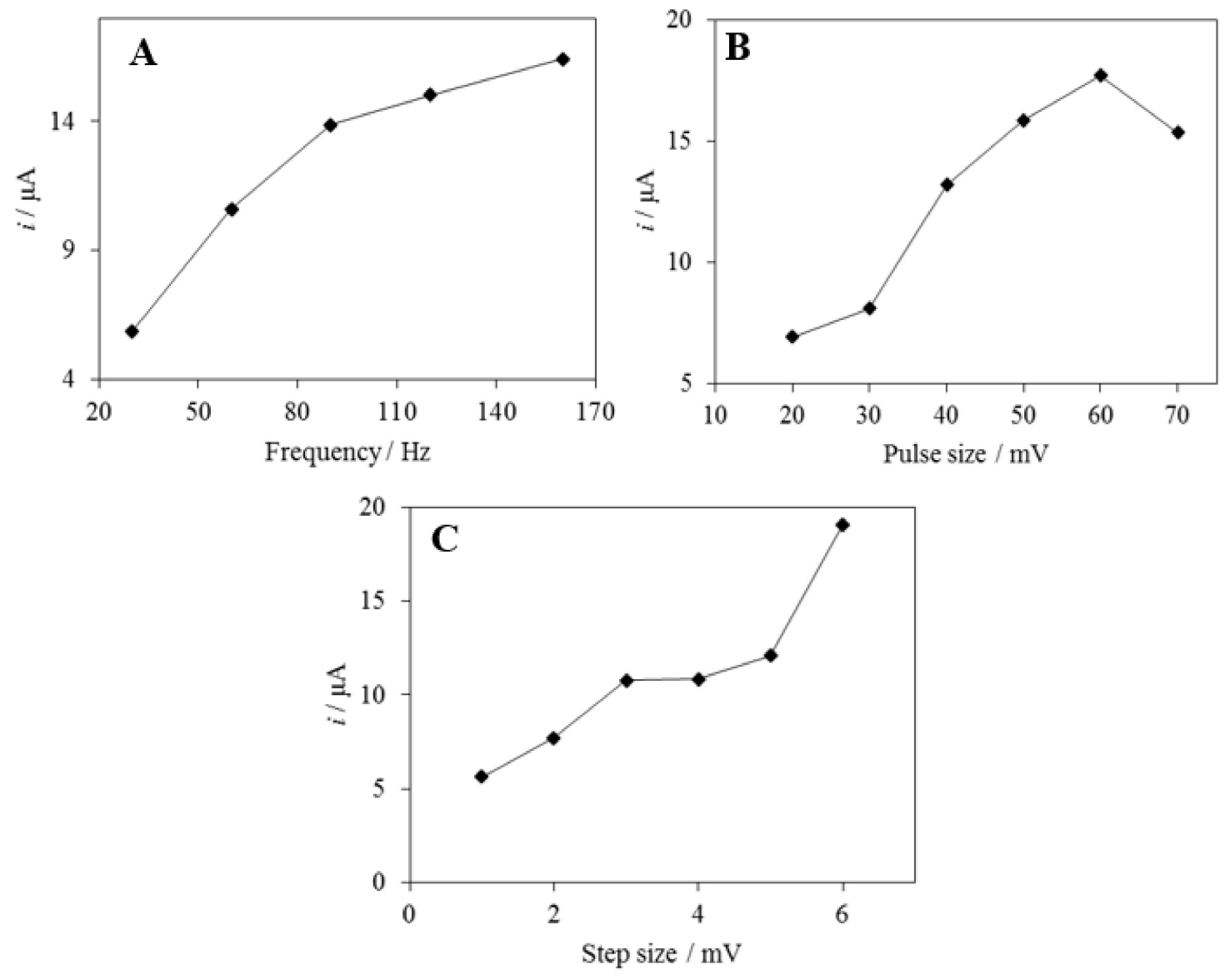

Figure 9. Effects of the SWV parameters (A) frequency, (B) pulse size, and (C) step size on current response. Solution: $0.1 \mathrm{mM}$ BPA.

\subsection{Effects of Scan Rate}

Figure 10 shows a cyclic voltammogram of $0.1 \mathrm{mM}$ BPA at Zn/Al-LDH-QC/MWCNT paste electrode with different scan rate $\left(25-250 \mathrm{mV} \mathrm{s}^{-1}\right)$. The current peak increased successively when the scan rate increase. Meanwhile, the inset graph shows the linear rising of the current peak with the increase of scan rate. The relationship can be described as: $I_{\mathrm{pa}}(\mu \mathrm{A})=0.0778 \mathrm{E}\left(\mathrm{mV} \mathrm{s}^{-1}\right)$ $+3.802\left(R^{2}=0.9825\right)$, which classified the BPA oxidation on Zn/Al-LDH-QC/MWCNT as an adsorption-controlled process. 


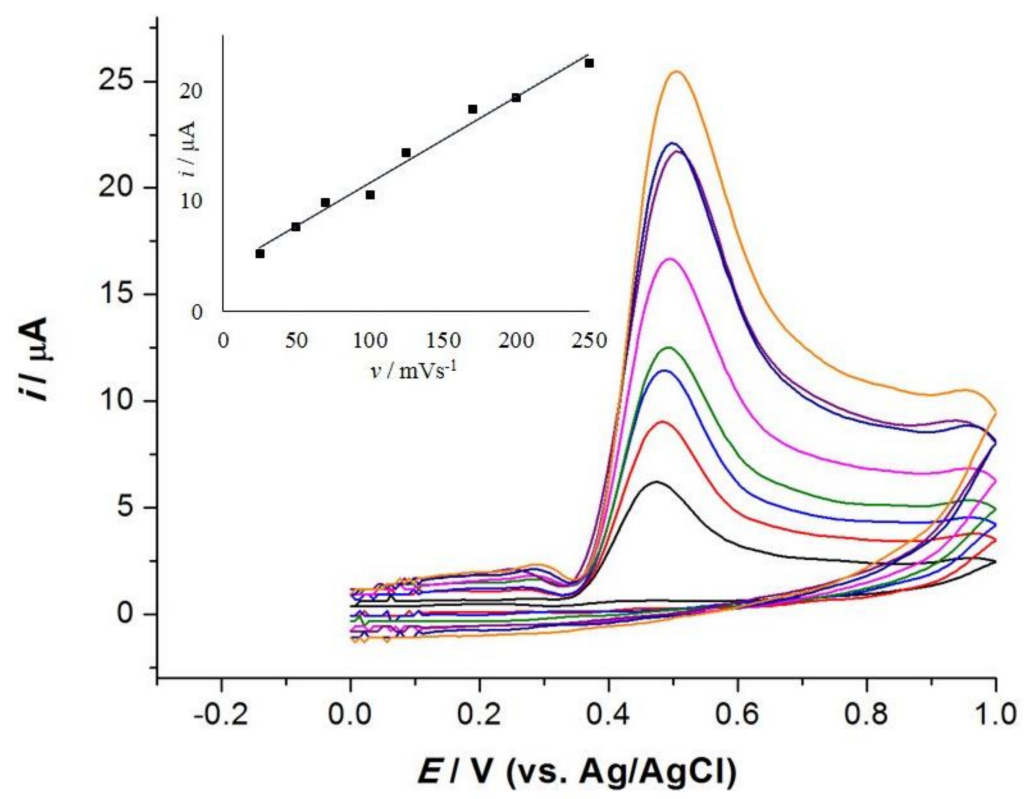

Figure 10. The cyclic voltammogram of $0.1 \mathrm{mM} \mathrm{BPA}$ at scan rate $25-250 \mathrm{mV} \mathrm{s}^{-1}$. (Inset graph: the plot of current peaks versus scan rate).

\subsection{Chronocoulometry Studies}

Chronocoulometry studies were performed in $4.0 \mathrm{mM} \mathrm{K}_{3}\left[\mathrm{Fe}(\mathrm{CN})_{6}\right]$ to investigate the effective electrochemical surface area of the MWCNT paste and Zn/Al-LDH-QC/MWCNT paste electrodes, based on the Anson equation (Equation (2));

11

$$
Q(t)=\frac{2 n F A c D^{\overline{2}} t^{\overline{2}}}{\pi^{\frac{1}{2}}}+Q_{\mathrm{dl}}+Q_{\mathrm{ads}}
$$

where, $Q(t)=$ Charge (Coulombs); $n=$ Number of electron transfer; $\mathrm{F}=$ Faraday constant $(96485$ Coulombs/mole); $A=$ Effective electrochemical surface area $\left(\mathrm{cm}^{2}\right) ; c=$ Concentration of substrate $\left(\mathrm{mole} / \mathrm{cm}^{3}\right) ; D=$ Diffusion coefficient of $\mathrm{K}_{3}\left[\mathrm{Fe}(\mathrm{CN})_{6}\right]\left(7.6 \times 10^{-6} \mathrm{~cm}^{2} \mathrm{~s}^{-1}\right) ; t=$ Time (s); $Q_{\mathrm{dl}}=$ Double layer charge (Coulombs); $Q_{\mathrm{ads}}=$ Faradaic charge (Coulombs).

According to the slopes of the plots of $Q$ vs. $t^{1 / 2}$ (Figure 11A), the effective electrochemical surface area for MWCNT paste electrode was calculated as $1.103 \mathrm{~cm}^{2}$, and $1.660 \mathrm{~cm}^{2}$ for $\mathrm{Zn} / \mathrm{Al}-\mathrm{LDH}-\mathrm{QC} / \mathrm{MWCNT}$ paste electrode. These indicated that the modification of MWCNT paste electrode with $\mathrm{Zn} / \mathrm{Al}-\mathrm{LDH}-\mathrm{QC}$ increased the electrode effective surface area. This phenomenon would increase the site of BPA oxidation, increase current response, and further improve the electrochemical performance of the sensor [36]. Then, the chronocoulometry experiments were carried out on $\mathrm{Zn} / \mathrm{Al}-\mathrm{LDH}-\mathrm{QC} / \mathrm{MWCNT}$ paste electrode in $0.1 \mathrm{mM}$ BPA. After background subtraction, the plot of charge $(Q)$ against the square root of time $\left(t^{1 / 2}\right)$ (Figure 11B), exhibited a linear relationship with slope and $Q_{\mathrm{ads}}$ of $1.98 \times 10^{-5} \mathrm{C}$ and $1.47 \times 10^{-5} \mathrm{C}$, respectively. Hence, $D$ was calculated to be $5.47 \times 10^{-4} \mathrm{~cm}^{2} \mathrm{~s}^{-1}$. Based on the Cottrell equation, $Q_{\mathrm{ads}}=n F A \Gamma_{\mathrm{s}}$, the adsorption capacity, $\Gamma_{\mathrm{s}}$, can be obtained as $4.58 \times 10^{-11} \mathrm{~mol} \mathrm{~cm}^{-2}$. The $\Gamma_{s}$ was higher than LDH/GCE $\left(1.10 \times 10^{-11} \mathrm{~mol} \mathrm{~cm}^{-2}\right)$ [37] and PAMAM $/ \mathrm{Fe}_{3} \mathrm{O}_{4} / \mathrm{GCE}\left(4.22 \times 10^{-11} \mathrm{~mol} \mathrm{~cm}^{-2}\right)$ [38]. This contributes to a good detection of BPA due to high surface coverage owned by the modified electrode. 

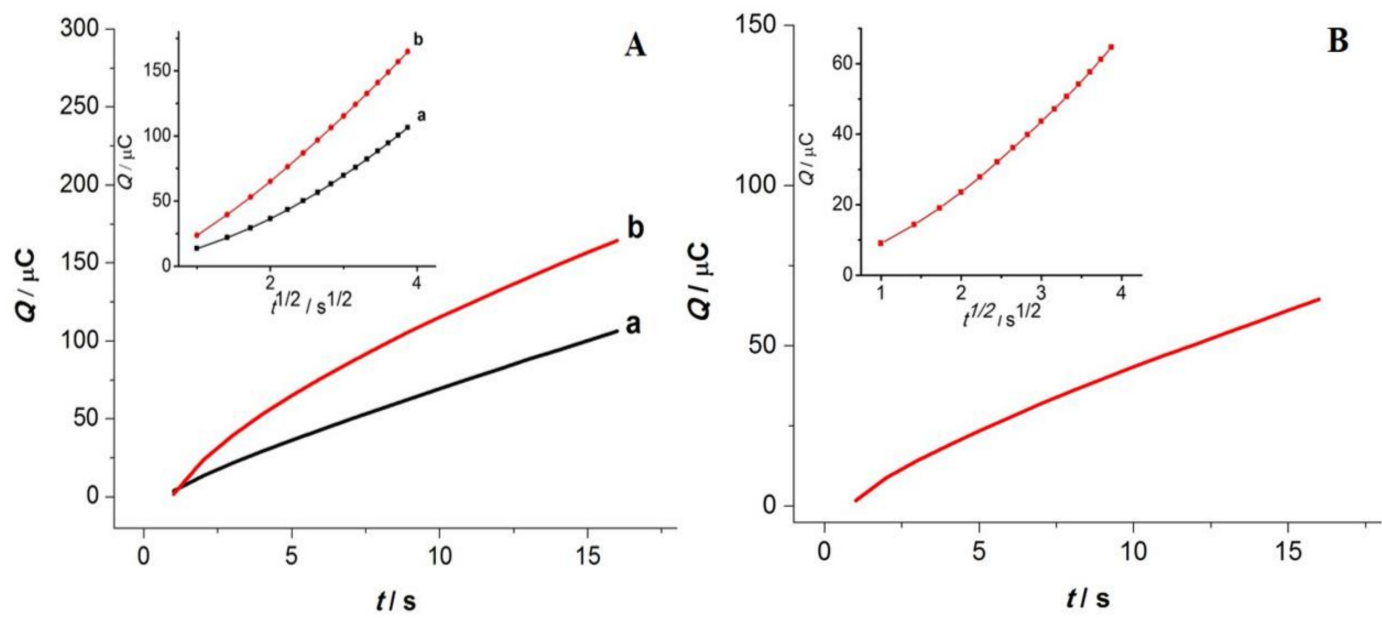

Figure 11. (A) The chronocoulograms of (a) MWCNT paste electrode, and (b) Zn/Al-LDH-QC/MWCNT paste electrode in $4.0 \mathrm{mM} \mathrm{K}_{3}\left[\mathrm{Fe}(\mathrm{CN})_{6}\right]$, (B) The chronocoulograms of $\mathrm{Zn} / \mathrm{Al}-\mathrm{LDH}-\mathrm{QC} / \mathrm{MWCNT}$ paste electrode in $0.1 \mathrm{mM}$ BPA.

\subsection{Calibration Curve}

The square-wave voltammogram in Figure 12 shows that $I_{\mathrm{pa}}$ increases linearly with concentration of BPA. The peak currents were linear with the concentration of BPA over three intervals in the range of $3.0 \times 10^{-8}-7.0 \times 10^{-7} \mathrm{M}\left(R^{2}=0.9876\right), 1.0 \times 10^{-6}-1.0 \times 10^{-5} \mathrm{M}\left(R^{2}=0.9836\right)$, and $3.0 \times 10^{-5}-3.0$ $\times 10^{-4} \mathrm{M}\left(R^{2}=0.9827\right)$. The equation expressed as $I_{\mathrm{pa}}(\mu \mathrm{A})=-0.3801 \log [\mathrm{BPA}]+3.206, I_{\mathrm{pa}}(\mu \mathrm{A})=$ $-2.076 \log [\mathrm{BPA}]+13.26$, and $I_{\mathrm{pa}}(\mu \mathrm{A})=-12.66 \log [\mathrm{BPA}]+61.95$. The detection limit was $4.4 \times 10^{-9}$ $\mathrm{M}(\mathrm{S} / \mathrm{N}=3)$. The data obtained were compared with the other related published papers as listed in Table 1. Scheme 2 illustrates the reaction mechanism occurred at the Zn/Al-LDH-QC/MWCNT paste electrode and BPA solution. In a solution, BPA was oxidized by releasing two electrons and protons, while in an electrode surface, QC in an interlayer Zn/Al-LDH accepting those electrons and protons.

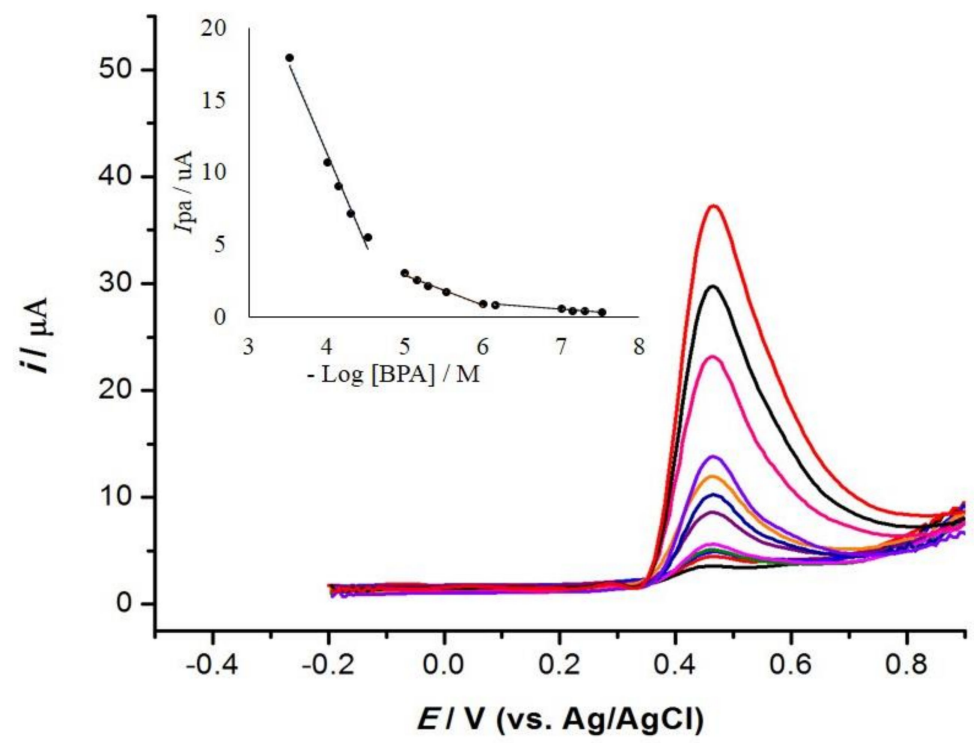

Figure 12. The square-wave voltammogram of various concentration of BPA. (Inset graph: calibration plot of various concentration of BPA). 
Table 1. The linear range and detection limit of different modified electrodes for the BPA determination.

\begin{tabular}{|c|c|c|c|c|}
\hline Modifier & Electrode & Linear Range $(\mu \mathrm{M})$ & LOD (nM) & Ref. \\
\hline ILs/Zn-Al-LDH & GCE & $0.02-3.00$ & 4.6 & [39] \\
\hline Exfoliated $\mathrm{Ni}_{2} \mathrm{Al}-\mathrm{LDH}$ nanosheets & $\mathrm{GCE}^{1}$ & $0.02-1.51$ & 6.8 & [40] \\
\hline $\mathrm{Fe}_{3} \mathrm{O}_{4} / \mathrm{AuNPs}$ & GCE & $0.02-1.40$ & 7.0 & [21] \\
\hline Na-doped $\mathrm{WO}_{3}$ nanorods & $\mathrm{CPE}^{2}$ & $0.08-22.5$ & 28.0 & [41] \\
\hline MWCNT/AuNPs & GCE & $0.01-0.70$ & 4.0 & [42] \\
\hline DPNs/PEI-PC & $\mathrm{SPCE}^{3}$ & $\begin{array}{l}0.01-1.00 \text {, and } \\
1.00-300\end{array}$ & 6.63 & [43] \\
\hline $\mathrm{MIP} / \mathrm{CNTs}-\mathrm{Au} / \mathrm{BOMC}$ & GCE & $0.01-10.0$ & 5.0 & [44] \\
\hline $\mathrm{CuPC} / \mathrm{MWCNT}-\mathrm{COOH}$ & PGE $^{4}$ & $0.10-27.5$ & 18.9 & [45] \\
\hline $\mathrm{Rh}_{2} \mathrm{O}_{3} / \mathrm{rGO}$ & GCE & $0.60-40.0$ & 120.0 & [46] \\
\hline US-MagMIP/CBNPs & SPCE & $0.07-10.0$ & 8.8 & [47] \\
\hline IL/GNPs & GCPE $^{5}$ & $0.02-5.00$ & 6.4 & [48] \\
\hline Zn/Al-LDH-quinclorac/MWCNT & CPE & $\begin{array}{c}0.03-0.70, \\
1.00-10.0, \text { and } \\
30.0-300\end{array}$ & 4.4 & This work \\
\hline
\end{tabular}

${ }^{1}$ GCE: glassy carbon electrode; ${ }^{2}$ CPE: carbon paste electrode; ${ }^{3}$ SPCE: screen printed carbon electrode; ${ }^{4}$ PGE: pencil graphite electrode; ${ }^{5} \mathrm{GCPE}$ : glassy carbon paste electrode.

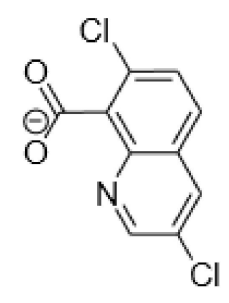

Quinclorac
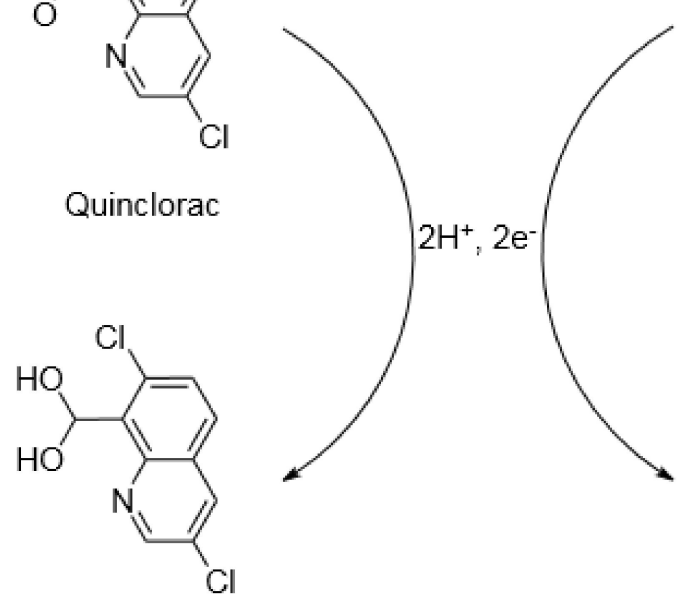

\section{Bisphenol A}

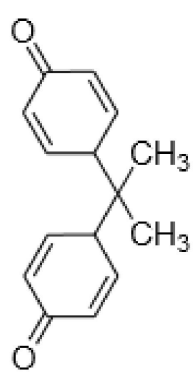

Scheme 2. The proposed mechanism at the Zn/Al-LDH-QC/MWCNT paste electrode and BPA solution.

\subsection{Reproducibility, Stability and Interferences}

There are many parameters influenced the sensor performance, mainly the reproducibility and the stability of the electrode. To evaluate the reproducibility of Zn/Al-LDH-QC/MWCNT paste electrodes, triplicate $\mathrm{Zn} / \mathrm{Al}-\mathrm{LDH}-\mathrm{QC} / \mathrm{MWCNT}$ paste electrodes were prepared and applied in the determination of in $0.1 \mathrm{mM}$ BPA. The relative standard deviation (RSD) obtained was $1.92 \%(n=3)$, indicates a high reproducible of sensor preparation method. Moreover, after one month, the current response of $0.1 \mathrm{mM}$ BPA retained $96.6 \%$ of the initial current indicates that the modified has good stability. 
The selectivity of the modified electrode was investigated by measuring the response $0.1 \mathrm{mM}$ BPA in the existence of some potential coexisting substances such as $\mathrm{Al}^{3+}, \mathrm{Cu}^{2+}, \mathrm{K}^{+}, \mathrm{Mg}^{2+}, \mathrm{Na}^{+}, \mathrm{Ni}^{2+}, \mathrm{Zn}^{2+}$, $\mathrm{NO}_{3}{ }^{-}, \mathrm{SO}_{4}{ }^{2-}$, dopamine, acetaminophen, and ethanol. Figure 13 summarizes the effect of $1.0 \mathrm{mM}$ and $5.0 \mathrm{mM}$ excess concentration of the possible interferences towards the detection of $0.1 \mathrm{mM}$ BPA. Overall, the peak current change was less than $\pm 15 \%$, which ascribed a good anti-interference ability of the modified electrode.

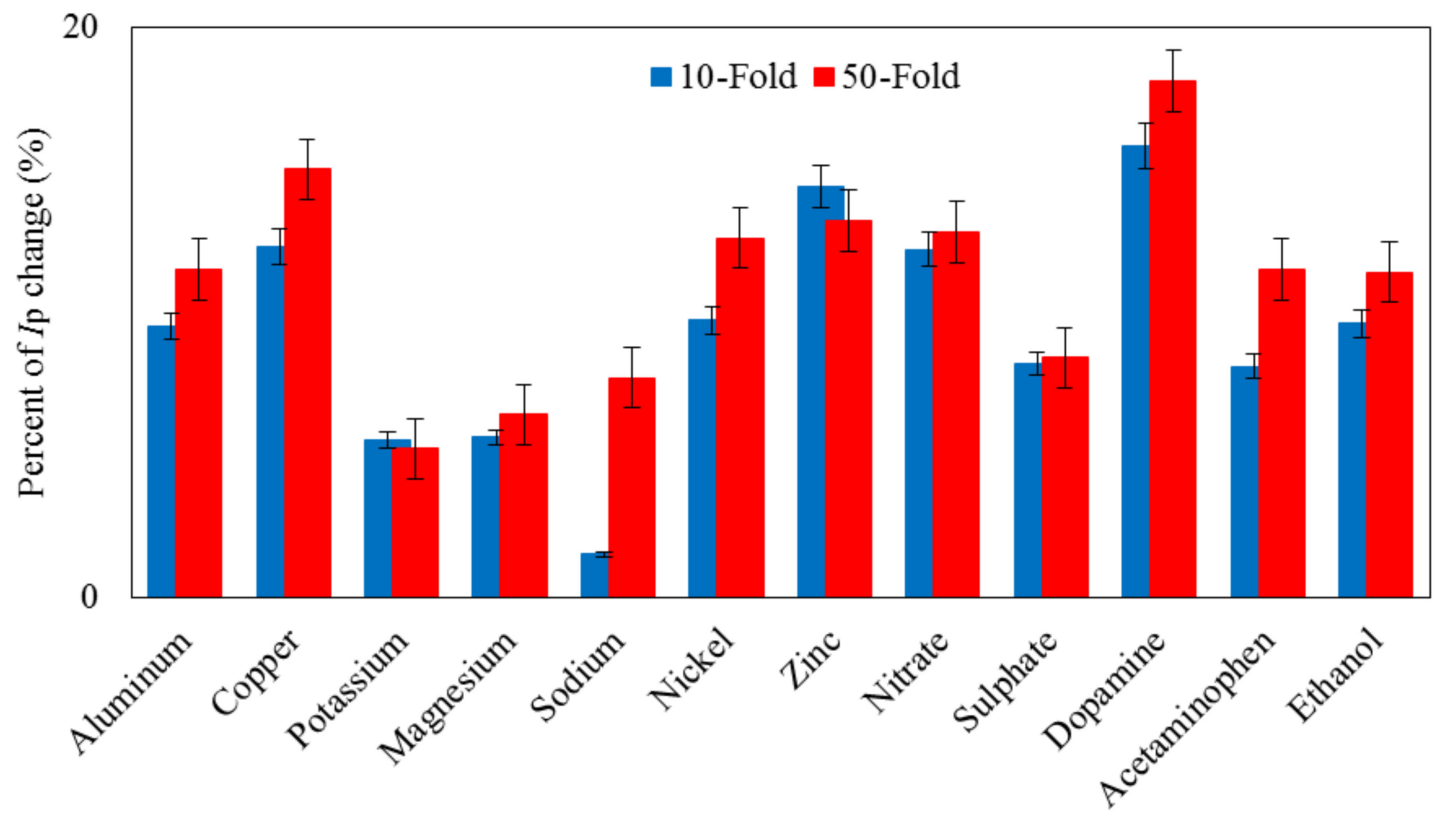

Figure 13. The influence of interferences in determination of $0.1 \mathrm{mM}$ BPA at Zn/Al-LDH-QC/MWCNT paste electrode.

\subsection{Real Samples}

The feasibility of Zn/Al-LDH-QC/MWCNT paste electrode in the determination of BPA in real samples was evaluated by performing the analysis in baby bottle and mineral water samples. Since BPA is not detected from both samples, the sample solutions were spiked with standard BPA solutions at different concentrations. Percent recoveries found were in the range of $98.22 \%$ and $101.02 \%$ (Table 2). These indicate good reliability of the sensor for real samples analysis.

Table 2. Recoveries of BPA in tap water sample and baby bottle $(n=3)$.

\begin{tabular}{ccccc}
\hline Real Aample & $\begin{array}{c}\text { BPA Detected } \\
(\mu \mathbf{M})\end{array}$ & $\begin{array}{c}\text { BPA Added } \\
(\mu \mathbf{M})\end{array}$ & $\begin{array}{c}\text { BPA Found } \\
(\mu \mathbf{M})\end{array}$ & Recovery (\%) \\
\hline Baby bottle & N.D. ${ }^{1}$ & 8 & $7.985 \pm 0.19^{2}$ & 99.81 \\
Mineral water 1 & N.D. & 15 & $14.73 \pm 0.56$ & 98.22 \\
Mineral water 2 & N.D. & 15 & $15.15 \pm 0.60$ & 101.02 \\
\hline
\end{tabular}

${ }^{1}$ Not detected; ${ }^{2}$ Average \pm Standard deviation.

\section{Conclusions}

The role of $\mathrm{Zn} / \mathrm{Al}-\mathrm{LDH}-\mathrm{QC}$ as a mediator in BPA determination was successfully demonstrated. The proposed electrode shows a good conductivity with high electron-transfer rate through $\mathrm{CV}$ and EIS studies. The effective electrochemical surface area of the electrodes was also investigated by chronocoulometry studies. The electrode exhibits a large effective electrochemical surface area and high adsorption capacity. At optimal condition, the electrode shows a wide linear working concentration range with detection limit of $4.4 \mathrm{nM}$. The electrode is also applicable for BPA analysis in baby bottle and mineral water samples with good recoveries. 
Author Contributions: Formal analysis, S.M.; Methodology, M.S.A.; Supervision, N.H.; Validation, R.Z.; Writing-original draft, N.A.A. and M.I.S.; Writing—review \& editing, I.M.I.

Funding: This research was funded by Ministry of Education Malaysia and Sultan Idris Education University, grant number 2017-0075-101-02. We also thank the Government of the Republic of Indonesia, Ministry of Technology, Research and Higher Education and Rector of Universitas Negeri Padang for grant number 1328/UN35.2/PG/2018 and 074/SP2H/LT/DRPM/2018.

Conflicts of Interest: The authors declare no conflicts of interest.

\section{References}

1. Rosu, D.; Mustata, F.; Tudorachi, N.; Musteata, V.E.; Rosu, L.; Varganici, C.D. Novel bio-based flexible epoxy resin from diglycidyl ether of bisphenol A cured with castor oil maleate. RSC Adv. 2015, 5, 45679-45687. [CrossRef]

2. Vom Saal, F.S.; Hughes, C. An extensive new literature concerning low-dose effects of bisphenol A shows the need for a new risk assessment. Environ. Health Perspect. 2005, 113, 926-933. [CrossRef] [PubMed]

3. Wu, L.; Deng, D.; Jin, J.; Lu, X.; Chen, J. Nanographene-based tyrosinase biosensor for rapid detection of bisphenol A. Biosens. Bioelectron. 2012, 35, 193-199. [CrossRef] [PubMed]

4. Welshons, W.V.; Thayer, K.A.; Judy, B.M.; Taylor, J.A.; Curran, E.M.; vom Saal, F.S. Large effects from small exposures. I. Mechanisms for endocrine-disrupting chemicals with estrogenic activity. Environ. Health Perspect. 2003, 111, 994-1006. [CrossRef] [PubMed]

5. Segner, H.; Navas, J.M.; Schäfers, C.; Wenzel, A. Potencies of estrogenic compounds in in vitro screening assays and in life cycle tets with zebrafish in vivo. Ecotoxicol. Environ. Saf. 2003, 54, 315-322. [CrossRef]

6. Chapin, R.E.; Adams, J.; Boekelheide, K.; Gray, L.E.; Hayward, S.W.; Lees, P.S.; McIntyre, B.S.; Portier, K.M.; Schnorr, T.M.; Selevan, S.G.; et al. NTP-CERHR expert panel report on the reproductive and developmental toxicity of bisphenol A. Birth Defect Res. B 2008, 83, 157-395. [CrossRef] [PubMed]

7. Vandenberg, L.N.; Hauser, R.; Marcus, M.; Olea, N.; Welshons, W.V. Human exposure to bisphenol A (BPA). Reprod. Toxicol. 2007, 24, 139-177. [CrossRef] [PubMed]

8. Sun, Y.; Irie, M.; Kishikawa, N.; Wada, M.; Kuroda, N.; Nakashima, K. Determination of bisphenol A in human breast milk by HPLC with column-switching and fluorescence detection. Biomed. Chromatogr. 2004, 18, 501-507. [CrossRef] [PubMed]

9. Ferrer, E.; Santoni, E.; Vittori, S.; Font, G.; Mañes, J.; Sagratini, G. Simultaneous determination of bisphenol A, octylphenol, and nonylphenol by pressurized liquid extraction and liquid chromatography-tandem mass spectrometry in powdered milk and infant formulas. Food Chem. 2011, 126, 360-367. [CrossRef]

10. Azzouz, A.; Rascón, A.J.; Ballesteros, E. Simultaneous determination of parabens, alkylphenols, phenylphenols, bisphenol A and triclosan in human urine, blood and breast milk by continous solid-phase extraction and gas chromatography-mass spectrometry. J. Pharm. Biomedic. Anal. 2016, 119, 16-26. [CrossRef] [PubMed]

11. Zhuang, Y.F.; Zhou, M.; Gu, J.; Li, X.M. Spectrophotometric and high performance liquid chromatographic methods for sensitive determination of bisphenol A. Spectrochim. Acta A 2014, 122, 153-157. [CrossRef] [PubMed]

12. Zhang, X.F.; Zhu, D.; Huang, C.P.; Sun, Y.H.; Lee, Y.I. Sensitive detection of bisphenol A in complex samples by in-column molecularly imprinted solid-phase extraction coupled with capillary electrophoresis. Microchem. J. 2015, 121, 1-5. [CrossRef]

13. Zhang, J.; Zhao, S.Q.; Zhang, K.; Zho, J.Q. Cd-doped ZnO quantum dots-based immunoassay for the quantitative determination of bisphenol A. Chemosphere 2014, 95, 105-110. [CrossRef] [PubMed]

14. Amjadi, M.; Manzoori, J.L.; Hallaj, T. A novel chemiluminescence method for determination of bisphenol A based on the carbon dot-enhanced $\mathrm{HCO}_{3}-\mathrm{H}_{2} \mathrm{O}_{2}$. J. Lumin. 2015, 158, 160-164. [CrossRef]

15. Kaddar, N.; Bendridi, N.; Harthé, C.; de Ravel, M.R.; Bienvenu, A.-L.; Cuilleron, C.-Y.; Mappus, E.; Pugeat, M; Déchaud, H. Development of radioimmunoassay for the measurement of bisphenol A in biological samples. Anal. Chim. Acta 2009, 645, 1-4. [CrossRef] [PubMed]

16. Li, H.; Wang, W.; Lv, Q.; Xi, G.; Bai, H.; Zhang, Q. Disposable paper-based electrochemical sensor based on stacked gold nanoparticles supported carbon nanotubes for the determination of bisphenol A. Electrochem. Commun. 2016, 68, 104-107. [CrossRef] 
17. Huang, Y.; Li, X.; Zheng, S. A novel and label-free immunosensor for bisphenol A using rutin as the redox probe. Talanta 2016, 160, 241-246. [CrossRef] [PubMed]

18. Huang, K.J.; Liu, Y.J.; Liu, Y.M.; Wang, L.L. Molybdenum disulfide nanoflower-chitosan-Au nanoparticles composites based electrochemical sensing platform for bisphenol A determination. J. Hazard. Mater. 2014, 276, 207-215. [CrossRef] [PubMed]

19. Goulart, L.A.; Mascaro, L.H. GC electrode modified with carbon nanotubes and NiO for the simultaneous determination of bisphenol A, hydroquinone and catechol. Electrochim. Acta 2016, 196, 48-55. [CrossRef]

20. Nilkahd, B.; Khalilzadeh, M.A. Liquid phase determination of bisphenol A in food samples using novel nanostructure ionic liquid modified sensor. J. Mol. Liq. 2016, 215, 253-257. [CrossRef]

21. Santana, E.R.; de Lima, C.A.; Piovesa, J.V.; Spinelli, A. An original ferroferric oxide and gold nanoparticles-modified glassy carbon electrode for the determination of bisphenol A. Sens. Actuators B 2017, 240, 487-496. [CrossRef]

22. Hou, C.; Tang, W.; Zhang, C.; Wang, Y.; Zhu, N. A novel and sensitive electrochemical sensor for bisphenol A determination based on carbon black supporting ferroferric oxide nanoparticles. Electrochim. Acta 2014, 144, 324-331. [CrossRef]

23. Peng, L.; Dong, S.; Xie, H.; Gu, G.; He, Z.; Lu, J.; Huang, T. Sensitive simultaneous determination of diethylstilbestrol and bisphenol $\mathrm{A}$ based on $\mathrm{Bi}_{2} \mathrm{WO}_{6}$ nanoplates modified carbon paste electrode. J. Electroanal. Chem. 2014, 726, 15-20. [CrossRef]

24. Wardani, N.I.; Isa, I.M.; Hashim, N.; Ghani, S.A. Zinc layered hydroxide-2(3-chlorophenoxy)propionate modified multiwalled carbon nanotubes paste electrode for the determination of nanomolar levels copper(II). Sens. Actuators B 2014, 198, 243-248. [CrossRef]

25. Isa, I.M.; Sharif, S.N.M.; Hashim, N.; Ghani, S.A. Amperometric determination of nanomolar mercury (II) by layered double nanocomposite of zinc/aluminium hydroxide-3(4-methoxyphenyl) propionate modified single-walled carbon nanotube paste electrode. Ionics 2015, 21, 2949-2958. [CrossRef]

26. Isa, I.M.; Fasyir, M.R.; Hashim, N.; Ghani, S.A.; Bakar, S.A.; Mohamed, A.; Kamari, A. A highly sensitive mercury (II) sensor using Zn/Al layered double hydroxide-3(4-hydroxyphenyl) propionate modified multi-walled carbon nanotube paste electrode. Int. J. Electrochem. Sci. 2015, 10, 6227-6240.

27. Sharif, S.N.M.; Hashim, N.; Isa, I.M.; Ali, N.M.; Bakar, S.A.; Hussein, M.Z.; Mamat, M.; Bakar, N.A.; Mahamod, W.R.W. Preparation and characterization of novel paddy cultivation herbicide nanocomposite from zinc/aluminium layered double hydroxide and quinclorac anion. Mater. Res. Innov. 2018, 1-6. [CrossRef]

28. Concenco, G.; Silva, A.F.; Ferreira, E.A.; Galon, L.; Noldin, J.A.; Aspiazu, I.; Ferreira, F.A.; Silva, A.A. Effect of dose and application site on quinclorac absorption by barnyardgrass biotypes. Planta Daninha 2009, 27, 541-548. [CrossRef]

29. Sljukic, B.; Banks, C.E.; Crossley, A.; Compton, R.G. Iron (III) oxide graphite composite electrodes: application to the electroanalytical detection of hydrazine and hydrogen peroxide. Electroanalysis 2006, 18, 1757-1762. [CrossRef]

30. Keyvanfard, M.; Shakeri, R.; -Maleh, H.K.; Alizad, K. Highly selective and sensitive voltammetric sensor based on modified multiwall carbon nanotube paste electrode for simultaneous determination of ascorbic acid, acetaminophen and tryptophan. Mater. Sci. Eng. C 2013, 33, 811-816. [CrossRef] [PubMed]

31. Zeng, Y.; Zhu, Z.; Du, D.; Lin, Y. Nanomaterial-based electrochemical biosensors for food safety. J. Electroanal. Chem. 2016, 781, 147-154. [CrossRef]

32. D’Souza, O.J.; Mascarenhas, R.J.; Thomas, T.; Basavaraja, B.M.; Saxena, A.K.; Mukhopadhyay, K.; Roy, D. Platinum decorated multi-walled carbon nanotubes/Triton X-100 modified carbon paste electrode for the sensitive amperometric determination of paracetamol. J. Elec. Chem. 2015, 739, 49-57. [CrossRef]

33. Apodaca, D.C.; Pernites, R.B.; Ponnapati, R.; Mundo, F.R.D.; Advincula, R.C. Electropolymerized molecularly imprinted polymer film: EIS sensing of bisphenol A. Macromoleculec 2011, 44, 6669-6682. [CrossRef]

34. Su, B.; Shao, H.; Li, N.; Chen, X.; Chai, Z.; Chen, X. A sensitive bisphenol A voltammetric sensor relying on AuPd nanoparticles/graphene composites modified glassy carbon electrode. Talanta 2017, 166, 126-132. [CrossRef] [PubMed]

35. Osteryoung, J.G.; Osteryoung, R.A. Square-wave voltammetry. Anal. Chem. 1985, 57, 101A-102A. [CrossRef]

36. Dong, X.; Qi, X.; Liu, N.; Yang, Y.; Piao, Y. Direct electrochemical detection of bisphenol A using a highly conductive graphite nanoparticles film electrode. Sensors 2017, 17, 836. [CrossRef] [PubMed] 
37. Cosio, M.S.; Pellicano, A.; Brunetti, B.; Fuenmayor, C.A. A simple hydroxylated multi-walled carbon nanotubes modified glassy carbon electrode for rapid amperometric detection of bisphenol A. Sens. Actuators B 2017, 246, 673-679. [CrossRef]

38. Ghanam, A.; Lahcen, A.A.; Amine, A. Electroanalytical determination of bisphenol A: Investigation of electrode surface fouling using various carbon materials. J. Electroanal. Chem. 2017, 789, 58-66. [CrossRef]

39. Zhan, T.; Song, Y.; Li, X.; Hou, W. Electrochemical sensor for bisphenol A based on ionic liquid functionalized Zn-Al layered double hydroxide modified electrode. Mater. Sci. Eng. C 2016, 64, 354-361. [CrossRef] [PubMed]

40. Zhan, T.; Song, Y.; Tan, Z.; Hou, W. Electrochemical bisphenol A sensor based on exfoliated Ni ${ }_{2} \mathrm{Al}_{\text {-layered }}$ double hydroxide nanosheets modified electrode. Sens. Actuators B 2017, 238, 962-971. [CrossRef]

41. Zhou, Y.; Yang, L.; Li, S.; Dang, Y. A novel electrochemical sensor for highly sensitive detection of bisphenol A based on the hydrothermal synthesized Na-doped $\mathrm{WO}_{3}$ nanorods. Sens. Actuators B 2017, 245, 238-246. [CrossRef]

42. Messaoud, N.B.; Ghica, M.E.; Dridi, C.; Ali, M.B.; Brett, C.M.A. Electrochemical sensor based on multiwalled carbon nanotube and gold nanoparticle modified electrode for the sensitive detection of bisphenol A. Sens. Actuators B 2017, 253, 513-522. [CrossRef]

43. Shim, K.; Kim, J.; Shahabuddin, M.; Yamauchi, Y.; Hossain, M.S.A.; Kim, J.H. Efficient wide range electrochemical bisphenol-A sensor by self-supported dendritic nanoparticles on screen-printed carbon electrode. Sens. Actuators B 2017, 255, 2800-2808. [CrossRef]

44. Hu, X.; Feng, Y.; Wang, H.; Zhao, F.; Zeng, B. A novel bisphenol A electrochemical sensor based on a molecularly imprinted polymer/carbon nanotubes-Au nanoparticles/boron-doped ordered mesoporous carbon composite. Anal. Methods 2018, 10, 4543-4548. [CrossRef]

45. Koyun, O.; Gorduk, S.; Gencten, M.; Sahin, Y. A novel copper (II) phthalocyanine-modified multiwalled carbon nanotube-based electrode for sensitive electrochemical detection of bisphenol A. New J. Chem. 2019, 43, 85-92. [CrossRef]

46. Shi, R.; Yuan, X.; Liu, A.; Xu, M.; Zhao, Z. Determination of bisphenol A in beverages by an electrochemical sensor based on $\mathrm{Rh}_{2} \mathrm{O}_{3}$ /reduced grapheme oxide composites. Appl. Sci. 2018, 8, 2535. [CrossRef]

47. Messaoud, N.B.; Lahcen, A.A.; Dridi, C.; Amine, A. Ultrasound assisted magnetic imprinted polymer combined sensor based on carbon black and gold nanoparticles for selective and sensitive electrochemical detection of bisphenol A. Sens. Actuators B 2018, 276, 304-312. [CrossRef]

48. Butmee, P.; Tumcharern, G.; Saejueng, P.; Stankovic, D.; Ortner, A.; Jitcharoen, J.; Kalcher, K.; Samphao, A. A direct and sensitive electrochemical sensing platfor baed on ionic liquid functionalized grapheme nanoplatelets for the detection of bisphenol A. J. Electroanal. Chem. 2019, 833, 370-379. [CrossRef] 